Research Article

\title{
Improving higher-order thinking skill through POE (Predict, Observe, Explain) and guided discovery learning models
}

Witriyani Suryamiati a,1,*, Adi Pasah Kahar a,2, Anandita Eka Setiadi a,3

a Department of Biology Education, Faculty of Teacher Training and Education, Universitas Muhammadiyah Pontianak,

Jl. Jend. Ahmad Yani 111, Pontianak, West Kalimantan 78123, Indonesia

${ }^{1}$ witriyaniadi@gmail.com ${ }^{*}$; adipasahkahar@gmail.com; ${ }^{3}$ anandita.eka@unmuhpnk.ac.id

${ }^{*}$ Corresponding author

\begin{tabular}{|c|c|}
\hline ARTICLE INFO & ABSTRACT \\
\hline $\begin{array}{l}\text { Article history } \\
\text { Received April 18, } 2019 \\
\text { Revised June 15, } 2019 \\
\text { Accepted June 22, } 2019 \\
\text { Published June 30, } 2019\end{array}$ & $\begin{array}{l}\text { The low level of students' higher-order thinking skills (HOTS) has been the main problem } \\
\text { of education in Indonesia. This study aimed to determine the difference of students' HOTS } \\
\text { taught by using POE and Guided discovery learning models. This quasi-experimental } \\
\text { research involved } 34 \text { students of X IPA } 3 \text { and } 32 \text { students of X IPA } 4 \text { at SMA Negeri } 1 \\
\text { Sungai Ambawang-West Kalimantan as the sample. The data obtained by using test which } \\
\text { was analyzed using Mann-Whitney U test. The results showed that the students' HOTS } \\
\text { who were treated with POE was significantly higher than those who were taught using } \\
\text { Guided discovery learning. Therefore, it is suggested to implement POE to improve } \\
\text { students' HOTS. }\end{array}$ \\
\hline \multicolumn{2}{|c|}{$\begin{array}{l}\text { How to cite: Suryamiati, W., Kahar, A. P., \& Setiadi, A. E. (2019). Improving higher-order thinking skill through POE (Predict, Observe, } \\
\text { Explain) and guided discovery learning model. JPBI (Jurnal Pendidikan Biologi Indonesia), 5(2), 245-252. doi: https:// } \\
\text { doi.org/10.22219/jpbi.v5i2.8266 }\end{array}$} \\
\hline
\end{tabular}

\section{INTRODUCTION}

In general, the Indonesian students' Higher-Order Thinking Skills (HOTS) are lower compared to other countries. It was proven by the Program for International Students Assessment (PISA) and Trend in the International Mathematics and Science Study (TIMSS) report which stated that Indonesian students were only able to achieve the second level of the six-thinking level in the competed questions. This report indicated the low ability of students in logical and rational thinking (Kayali \& Yilmaz, 2016). This condition led to Indonesia' achievement ranking in lower level compared to other participating countries (Sharma, 2013).

Low-order thinking taught at school makes the HOTS to be not developed well. In fact, HOTS are required to solve problems creatively and innovatively. In order to solve the problem, senior high school students need to be directed to develop the HOTS (Rochman \& Hartoyo, 2018). HOTS require not only the ability to remember but also the ability to analyze, to synthesize, and to evaluate (Yuriza et al., 2018). The analysis process involves the activities of differentiating, organizing, and associating. The evaluation process involves the activities of checking and critiquing. The creating process involves the activities of generating, planning, and producing (Hanoum, 2017). 
HOTS can be achieved with student-centered learning method. This kind of learning method allows students to express their ideas openly and to develop their HOTS (Sucipto, 2017). There are variety of learning models that can trigger student' activeness in finding out the concepts of knowledge; some of them are the POE learning model (Predict, Observe, Explain), and the guided discovery Learning Model. The POE learning model is one of the learning models derived from constructivism learning theory involving many students in its activities (Pamungkas, Mulyani, \& Saputro, 2017). One of the characteristics of the POE learning model is building the critical thinking skills of students (Mulyani, Saminan, \& Sulastri, 2017). Teaching activities consisting of POE assignments can be an alternative way to help change conceptions and improve students' concepts (Coştu, Ayas, \& Niaz, 2012). The POE learning model can be used by teachers to develop the learning activities and as early learning strategies that are appropriate for students (Rosdianto, Murdani, \& Hendra, 2017). POE learning model can improve on students' science process skills (Rini, Suryani, \& Fadhilah, 2018; Yulianti, Juanengsih, \& Mardiati, 2018).

The POE learning model directly involves students in the learning process by conducting experiments and obtains the knowledge gained more meaningful. The POE learning model can improve the skills of science processes and student learning outcomes (Hsiao et al., 2017). The POE learning model encourages students to create a hypothesis of a phenomenon or event, to observe through demonstrations or experiments and ultimately to explain the results of their experiments and their hypothesis (Astuti, Sulianto, \& Purnamasari, 2018). The POE learning model has 3 main steps, namely, Predicting, Observing, and Explaining (Ayvaci, 2013; Coştu et al., 2012).

The guided discovery learning model is a development of the discovery learning model (Yurahly, Darmadi, \& Darsikin, 2014). Guided discovery learning model is a learning model that actively and independently involves students to learn and to find concepts or to solve a problem with guidance from the teacher (Hulukati, Zakiyah, \& Rustam, 2018). Guided discovery learning model is a part of the experimental method that provides deeper understanding to students (Saleh, 2018).

In the guided discovery learning model, students will play an active role because students will try to solve problems and to obtain certain meaningful knowledge especially in improving students' character and concept understanding (Wardani, Nurhayati, \& Safitri, 2016). In guided discovery learning model, students will pass a mental process to assimilate a concept and a principle. The mental process meant in this case is the activities of observing, classifying, making hypotheses, explaining, measuring and making conclusions (Riandari, Susanti, \& Suratmi, 2018). The guided discovery learning steps according to Khabibah, Masykuri, \& Maridi, (2017) include, Stimulation, Problem Statement, Data Collection, Data Processing, Verification, and Generalization. Based on the research conducted by Martaida, Bukit, and Ginting, (2017) guided discovery learning model can improve students' critical thinking skills. The research conducted by Hidayatullah, Indrowati, and Sugihart, (2015) also revealed that Guided discovery learning models affect the naturalistic intelligence of students.

In its practical application, students' HOTS are rarely taught by using the POE learning model and guided discovery learning model. Some of the key features mentioned were the use of concept, inferences, visualization, and schemas, among others. Recommendations for practice change were made regarding the development of HOTS (Hassan, Mustapha, Yusuff, \& Mansor, 2017). This assumption can be proven by the research conducted by Noma, Prayitno, and Suwarno, (2016) who suggested increasing HOTS using the Problem Based Learning (PBL) model, and Treffinger model who was suggested by (Alhaddad, Kusumah, Sabandar, \& Dahlan, 2015).

Observation was conducted in X IPA 3 and X IPA 4 class using HOTS level test. There are 3 aspects in HOTS which are analyzing (C4), evaluating (C5), and creating (C6). Based on the observation, the average percentage result of analyzing aspect for class X IPA 3 is $43,46 \%$ and class X IPA 4 is $45,13 \%$, evaluating aspect for class X IPA 3 is $39,54 \%$ and class X IPA 4 is $43,07 \%$, and creating aspect for class X IPA 3 is $36,28 \%$ and class X IPA 4 is $40,63 \%$. Thus, the HOTS of both classes is categorized as low. According to Heong et al., (2011); Kusuma, Rosidin, and Suyatna, (2017) the percentage $50,25 \%-75 \%$ is categorized as good, meanwhile the percentage $25 \%-50 \%$ of HOTS is categorized as enough.

Students' HOTS is still low, it strenghtened with interview result. The interview was conducted with the biolody teacher and students. Based on the interview result, it can be known that the test used in biology lesson is still using lower-order thinking skill (LOTS) level (C1-C3 type) which categorized as low. According to Noma et al., (2016), C1 And C3 type of test still couldn't accomodate students to develop their HOTS optimally, so that the 3 aspects in the HOTS still couldn't be achieved by the students. Based on the interview with the students, it can be known that they tend memorize the material and less trained to develop their HOTS. Thus, based on the facts stated above, this research aimed to describe the difference of POE and guided discovery learning, also to find the effectiveness from those models against HOTS. 


\section{METHOD}

This study aims to determine the differences of students' HOTS taught by using POE and guided discovery learning models, and to determine the most effective learning models to improve HOTS. This research was conducted from January to february 2019. The research applied an experimental research method, in form of quasi experimental design. The research design was non-equivalent control group design (Sugiyono, 2014), with its design as follows in Table 1.

Table 1. Design non-equivalent control group design

\begin{tabular}{cccc}
\hline Class & Pre-test & Treatment & Post-test \\
\hline Experimental 1 & $\mathrm{O}_{1}$ & $\mathrm{X}$ & $\mathrm{O}_{2}$ \\
Experimental 2 & $\mathrm{O}_{1}$ & $\mathrm{X}$ & $\mathrm{O}_{2}$ \\
\hline
\end{tabular}

In this study, the pre-test was given to the experimental 1 and experimental 2. Then, the post-test as practiced to the experimental 1 students after they learn about Spermatopytha using POE learning model, meanwhile experimental 2 was given the guided discovery learning model. The population of this research was all Tenth $(X)$ grade students of SMA Negeri 1 Sungai Ambawang in academic year 2018/2019. The sampling technique was random sampling, as the homogeneity tests results the average score of students' Fungi daily test is homogeneous. The X IPA 3 class was selected as the experimental 1 and X IPA 4 class as the experimental 2. The primary variable of this study is the independent and dependent variable. The independent variable is POE and guided discovery learning model. The dependent variable in this study are high order thinking skills.

The instruments used in this study are test. The test was made according to some HOTS indicators which are analyzing, evaluating, and creating (Alhaddad et al., 2015; Kusuma et al., 2017). The form of the test used is two-tier multiple choice, which consist of two level, the first level is a test which have two alternative answers and the second level is the reason of the right answer based on the first level question.

Data analysis used to find out the difference of students' HOTS taught with POE and guided discovery learning model in spermatophyta is gain score with score provisons in Table 2 referring to Kurniawati and Maulana, (2019); Wulandari, Yamtinah, and Saputro, (2015), to determine the effective learning model for HOTS, the author used Normalized Gain (N-Gain) with equation Formula (1). The criteria of N-Gain is shown below in Table 3.

N.Gain $=\frac{\text { posttestscore }- \text { pretestscore }}{\text { maximumscore-pretestscore }}$

Table 2. Score two-tier test

\begin{tabular}{|c|c|c|}
\hline \multicolumn{2}{|c|}{ Students' Answers } & \multirow{2}{*}{ Score } \\
\hline First tier & Second tier & \\
\hline True & True & 3 \\
\hline True & False & 2 \\
\hline False & True & 1 \\
\hline False/not answering & False/not answering & 0 \\
\hline
\end{tabular}

Table 3. Range of gain values (N-Gain)

\begin{tabular}{ccc}
\multicolumn{3}{c}{ Table 3. Range of gain values (N-Gain) } \\
\hline Gain Values & Interpretation \\
\hline $\mathrm{g} \geq 0,7$ & High \\
$0,3 \leq \mathrm{g} \leq 0,7$ & Average/medium \\
$0<\mathrm{g}<0,3$ & Low \\
\hline
\end{tabular}

\section{RESULTS AND DISCUSSION}

\section{The difference between HOTS in POE experimental class and in guided discovery experimental class}

The result of data processed with Mann-Whitney $U$ test is shown in Table 4. The results of score Gain students' HOTS taught by using the POE learning model and guided discovery learning models are shown in Table 5.The result of HOTS indicators achievement is shown in Table 6.

Table 4. The result of Mann-Whitney $U$ test

\begin{tabular}{ccc}
\multicolumn{4}{c}{ Table 4. The result of Mann-Whitney Uest } & Sig. \\
\hline Test & Score & $<0.05$ \\
\hline Mann-Whitney U & 250.000 & \\
\hline
\end{tabular}


JPBI (Jurnal Pendidikan Biologi Indonesia)

Vol. 5, No. 2, July 2019, pp. 245-252

Table 5. Average score and gain value of HOTS

\begin{tabular}{cccc}
\hline \multirow{2}{*}{ Class } & \multicolumn{2}{c}{ Average Score } & \multirow{2}{*}{ Gain } \\
\cline { 2 - 3 } & Pre-test & Post-test & \\
\hline POE & 40.82 & 71.09 & 30.26 \\
Guided discovery & 42.66 & 78.69 & 36.03 \\
\hline
\end{tabular}

Table 6. Indicator achievement of post-test

\begin{tabular}{ccr}
\hline Indicators & \multicolumn{2}{c}{ Class } \\
\cline { 2 - 3 } & POE (\%) & Guided Discovery (\%) \\
\hline Analyzing & 75.16 & 83.68 \\
Evaluating & 70.26 & 76.39 \\
Creating & 67.64 & 81.77 \\
\hline
\end{tabular}

Based on Table 4, it was found that the average gain value of the POE experimental class was 30.26 and the guided discovery experimental class values was 36.03 so that it can be inferred that both of the classes had different result. It was proven by the results of normality test in the POE experimental class that was $0.012<0.05$ and in the Guided discovery class that was $0.007<0.05$, then followed by the Mann-Whitney $U$ test which showed that the gain value of the POE experimental class and the gain value of the guided discovery class are $0.000<$ 0.05 . As the result, $H_{0}$ was rejected and there were different high-level thinking skills of students who were taught by using POE learning models and Guided discovery learning models.

The difference is due to the different treatments at each stage of the learning models. Riandari et al., (2018) mentioned the first activity of guided discovery learning was stimulation in which students are first directed to read books and given the opportunity to ask for something order to trigger their curiosity and willing to find the solution by themselves like the students read the literature given by teacher or any other references. This stage trained the analysis aspects, It is in line with Setiadi and Irhasyuarna, (2017), that a constructive learning model can increase students' analyzing skill.

The second stage is Problem Statement. In this stage, students are given the responsibility to make a hypothesis. This activity emerged empirical reasoning to understand the information obtained and identify various problems. Based on the process carried out in this activity, students are trained to improve the creating and analysis aspects. According to Wulan, Susanti, and Aisyah, (2017), explaining information is one of the indicators of analyzing. While, providing a hypothesis or initial idea is one of the indicators of creating. The aspect of analysis done by students on this syntax is choosing relevant information and associating them with the aspect of analysis done by students on this syntax is choosing relevant information and associating them with. The characteristic or Angiospermae which are; have flower as its reproductive organ, have tap roots and fiber roots, and divided into two based on the cotiledon (monocotyl and dicotyl).

The third stage is Data Collection. In this stage, students are given the opportunity to collect data by conducting observations to develop students' curiosity, and to motivate students to find the answers or solutions, the students' observ the Angiospermae plants and fit the information with the hypotesis they already made. The HOTS aspects that appear in this syntax are analysis, evaluation, and creating (Rubiyanto, Marjono, \& Prayitno, 2016). The aspect of the analysis done by students in this syntax is associating the information obtained in order to form new information. The evaluation aspect done by students is examining information obtained with the help of other references such as books and the internet to find out correctness of the information.

The fourth stage is data processing. In this stage, students conduct discussions and analysis in groups about the results of Collection data, the students observ the Angiospermae plants and fit the information with the hypotesis they already made. Through discussion, students will remember more about what they have been discussed. This is supported by Akintunde, (2017); Tan and So, (2019), who states that interaction with the environment can improve the understanding and enrich knowledge, especially for investigating learners' interaction with the physical environment to co-construct knowledge and to make interdisciplinary knowledge connections. The aspect trained in this syntax is analysis. The aspect of analysis is exchanging opinions based on the perspective of each student.

The fifth stage is Verification. In this stage, students verify the results of data, revision and justification of the results obtained, the students make report about their observation result and discussion. The aspects trained in this syntax are analysis, evaluation and creating. The aspect of analysis done by students on this syntax is choosing relevant information and associating it with other information. The evaluation aspect done by students at this stage is checking the information obtained to find out the truth of the relevant information or the effectiveness of that information. The last stage is Generalization. In this stage, students make conclusions of the learning process. The HOTS aspect trained in this syntax are analysis, evaluation, creates (Rubiyanto et al., 2016). 
On the other hand, the POE learning model only has 3 stages, namely Predicting, Observing, and Explaining. This is supported by Ayvaci, (2013); Coştu et al., (2012) which states that there are 3 steps of the POE learning model. Predicting is a process of making guesses or hypothesis about a phenomenon. In making the hypothesis, the students have thought about the reason why he made such a hypothesis. This stage trains the indicator of analysis and creating. Observing is a process of research and observations related to what happened. In other words, students are encouraged to conduct experiments and to test the truth. According to Ayvaci, (2013), POE was effective in teaching of abstract physics concepts in which both experiment and inquiry implemented together. The HOTS aspect this stage is analysis and evaluation. Last, Explaining is a process of giving an explanation, especially about the compatibility between the hypothesis and the experimental results from the observation stage. The aspects trained in this syntax are analysis and evaluation.

HOTS indicators achievement of the students which taught with Guided discovery learning model is better than the POE learning model. The analyzing HOTS indicator from guided discovery class got $83,68 \%$ compared to the analyzing indicator from POE class which got $75,16 \%$, it is because the analyzing indicator in guided discovery learning model is more often trained. The evaluating HOTS indicator in guided discovery class is better with percentage value of $76,39 \%$ compared to POE class with value percentage of $70,26 \%$, it is because the evaluating indicator is more often applied in guided discovery learning model stages which consist of data collection, verification, and generalization. The last indicator is creating, guided discovery class got $81,77 \%$ in creating indicator, meanwhile the POE class got $67,64 \%$, this is because the creating indicator taughtin guided discovery is more often trained in problem statement, verification, and generalization, meanwhile in POE only practiced in predict and explain stages.

Guided discovery learning model has the advantage in organizing students to learn, where the teacher will provide a problem that must be answered through an experiment. Though, this way, students will find out the solution to solve the problem and with instructions from teacher. The next stage is providing assistance or guidance in group investigations (Yurahly et al., 2014). An important phase in a guided learning model that must be considered is in phase 1 directs students to problems, phase 2 organizes students in learning, and phase 3 is investigations that guide individuals or groups (Setiadi \& Irhasyuarna, 2017).

\section{The effectiveness of the POE learning model and guided discovery learning model}

Based on the results of the research the effectiveness of the POE and Guided discovery learning models can be seen in the following Table 7.

Table 7. Effectiveness of HOTS in POE experimental class and guided discovery experimental class

\begin{tabular}{ccc}
\hline Criteria & \multicolumn{2}{c}{ Class } \\
\cline { 2 - 3 } & POE & GD \\
\hline Post-test Average Score & 71.09 & 78.69 \\
N-Gain Average Score & 0.52 & 0.64 \\
Classical Completeness (\%) & 26.47 & 65.62 \\
\hline
\end{tabular}

The effectiveness of both learning models was measured by using the N-Gain formula. N-Gain obtained in POE experimental class was 0.52 and N-Gain obtained in Guided discovery class was 0.64 . The result was categorize as medium, which was above or equal to 0.3 and below 0.7 . Between the two learning models, the most effective model in improving HOT skills is the Guided discovery learning model. However, the two learning models did not fulfill classical completeness Table 3.

The effectiveness of the learning model in improving students' high order thinking skills (HOTS) was measured using the N-Gain value. From the test, it was obtained that the N-Gain of POE learning model was 0.52 and the $\mathrm{N}$-Gain of guided discovery learning model was 0.64 . The average $\mathrm{N}$-Gain scores of both learning models were included as the medium category. Therefore, it can be said that both models have effectiveness in increasing HOTS of students although the classical completeness of the both learning models is still low. Based on the explanation above, it can be concluded that students' HOTS can be increased or developed if the process of learning by using both PEO and guided discovery learning model is conducted continuously (Mahfuzah, Munzil, \& Utomo, 2018). While in this research, the process of learning by using both of the learning models is conducted only within 2 months (January and February).

The N-Gain average score of the Guided discovery experiment was higher, which was 0.64 compared to the POE experimental $\mathrm{N}$-Gain average score of 0.52 . Therefore, it can be said from the two learning models, the guided discovery learning model is more effective in increasing HOTS. Higher order thinking skills can be improved with learning strategies that are able to foster high and deep level thinking skills. This is also supported by the research of Mahfuzah et al., (2018); Mulyani et al., (2017) that guided discovery learning model significantly enhanced students' HOTS with an average score. 
Guided discovery learning model has some strength (1) the engagement of the students is maximal, (2) the students are guided to find concept independently, (3) there is team work in solving the problems, (4) increases students' learning activities, (5) increases students' creativity and agility in solving the problems, (6) students' are trained to apply their knowledge in daily life (Hulukati et al., 2018; Sulistyowati, Widodo, \& Sumarni, 2012). By connecting learning materials and students' cognition structure in guided teaching, teachers provide a conceptual structure for students more stably (Lyu \& Wang, 2018; Martaida et al., 2017).

\section{CONCLUSION}

Based on the findings, the study reveals a significance differences of students' HOTS taught using POE learning model and guided discovery learning model. Guided discovery learning model was more effective in improving HOTS than POE learning model because the HOTS indicators are trained more often through the learning syntax in Guided discovery. It was proven from the results of the N-Gain test. The N-Gain of Guided discovery learning model was 0.64 and the N-Gain of POE learning model was 0.52 . However, the classical completeness of these learning models was still under the standard score, because to increase students' HOTS need to be done periodically and continuously so the students will be more skilled to develop their thinking skill.

\section{REFERENCES}

Akintunde, E. A. (2017). Theories and concepts for Human behavior in environmental preservation. Journal of Environmental Science and Public Health, 01(02), 120-133. doi: https://doi.org/10.26502/jesph.961200 12

Alhaddad, I., Kusumah, Y. S., Sabandar, J., \& Dahlan, J. A. (2015). Enhancing students' communication skills through treffinger teaching model. Journal on Mathematics Education, 6(1), 31-39. doi: https://doi.org/10. 22342/jme.6.1.1856.31-39

Astuti, M. R., Sulianto, J., \& Purnamasari, V. (2018). Keefektifan model predict-observe-explain terhadap kemampuan pemahaman konsep pada mata pelajaran IPA. Mimbar Sekolah Dasar, 4(3), 235-244. doi: https://doi.org/10.17509/mimbar-sd.v4i3.7876

Ayvaci, H. (2013). Investigating the predict-observe-explain strategy on teaching photo electricity. Journal of Baltic Science Education, 12(5), 548-565. Retrieved from http://oaji.net/articles/2015/987-14258101 46.pdf

Coştu, B., Ayas, A., \& Niaz, M. (2012). Investigating the effectiveness of a POE-based teaching activity on students' understanding of condensation. Instructional Science, 40(1), 47-67. doi: https://doi.org/10.1007/ s11251-011-9169-2

Hanoum, R. N. (2017). Mengembangkan keterampilan berpikir tingkat tinggi mahasiswa melalui media sosial. Edutech, 13(3), 400. doi: https://doi.org/10.17509/edutech.v13i3.3093

Hassan, M. N., Mustapha, R., Yusuff, N. A. N., \& Mansor, R. (2017). Development of higher order thinking skills module in science primary school: Needs analysis. International Journal of Academic Research in Business and Social Sciences, 7(2), 624-628. doi: https://doi.org/10.6007/JJARBSS/v7-i2/2670

Heong, Y. M., Widad Othman, Jailani Md Yunos, Kiong, T. T., Razali Hassan, \& Mimi Mohaffyza Mohamad. (2011). The level of marzano higher order thinking skills among technical education students. International Journal of Social Science and Humanity, 1(2), 121-125. Retrieved from http://ijssh.org/papers/20H009.pdf

Hidayatullah, muh syarif, Indrowati, M., \& Sugihart, B. (2015). The influence of guided discovery learning model with guided inquiry iased learning module based concerning to naturalistic intelligence VII Grade Student at SMP Muhammadiyah 8 Surakarta in academic year 2014/2015. Jurnal Pendidikan Biologi, 7(3), 8897. Retrieved from https://media.neliti.com/media/publications/119888-ID-none.pdf

Hsiao, H. S., Chen, J. C., Hong, J. C., Chen, P. H., Lu, C. C., \& Chen, S. Y. (2017). A five-stage predictionobservation-explanation inquiry-based learning model to improve students' learning performance in science courses. Eurasia Journal of Mathematics, Science and Technology Education, 13(7), 3393-3416. doi: https://doi.org/10.12973/eurasia.2017.00735a

Hulukati, E., Zakiyah, S., \& Rustam, A. (2018). The effect of guided discovery learning model with superitem test on students' problem-solving ability in mathematics. Journal of Social Science Studies, 5(2), 210. doi: https://doi.org/10.5296/jsss.v5i2.13406

Kayali, Ş., \& Yilmaz, M. (2016). An exploratory study to assess analytical and logical thinking skills of the software practitioners using a gamification perspective. Süleyman Demirel Üniversitesi Fen Bilimleri 
Enstitüsü Dergisi, 21(1), 178. doi: https://doi.org/10.19113/sdufbed.39411

Khabibah, E. N., Masykuri, M., \& Maridi, M. (2017). The effectiveness of module based on discovery learning to increase generic science skills. Journal of Education and Learning (EduLearn), 11(2), 146. doi: https:// doi.org/10.11591/edulearn.v11i2.6076

Kurniawati, H., \& Maulana, S. (2019). The implementation of chordophone enrichment book as an essential factor to create meaningful learning. Journal of Physics: Conference Series, 1157(3). doi: https://doi. org/10.1088/1742-6596/1157/3/032001

Kusuma, M. D., Rosidin, U., \& Suyatna, A. (2017). The development of Higher Order Thinking Skill (Hots) instrument assessment in physics study. IOSR Journal of Research \& Method in Education (IOSR-JRME), 7(1), 26-32. doi: https://doi.org/10.9790/7388-0701052632

Lyu, D., \& Wang, B. (2018). Effects of the application of computer network technology to guided discovery teaching on learning achievement and outcome. Eurasia Journal of Mathematics, Science and Technology Education, 14(7), 3269-3276. doi: https://doi.org/10.29333/ejmste/91249

Mahfuzah, B. A., Munzil, \& Utomo, Y. (2018). Efektivitas GDL (Guided Discovery Learning) dan problem solving terhadap KBK (Keterampilan Berpikir Kritis) dan HOTS (Higher Order Thingking Skills). Jurnal Pendidikan: Teori, Penelitian, Dan Pengembangan, 3(6), 739-744. doi: https://doi.org/10.17977/jptpp. v3i6.11131

Martaida, T., Bukit, N., \& Ginting, E. M. (2017). The effect of discovery learning model on student's critical thinking and cognitive ability in junior high school. losr-Jrme, 7(6), 1-8. doi: https://doi.org/10.9790/73880706010108

Megayani, \& Nurhalimah. (2017). Penerapan strategi Predict-Observe-Explain (POE) untuk meningkatkan hasil belajar siswa pada pokok bahasan pencemaran lingkungan di kelas VII SMP Negeri 2 Sumber Kabupaten Cirebon. Bio Educatio, 2(1), 58-62. Retrieved from https://media.neliti.com/media/publications/279477penerapan-strategi-predict-observe-expla-33732bd3.pdf

Mulyani, R., Saminan, S., \& Sulastri, S. (2017). Peningkatan kemampuan berpikir kritis peserta didik melalui implementasi lembar kerja peserta didik berbasis predict observe explain. Jurnal Pendidikan Sains Indonesia, 5(2), 19-24. doi: https://doi.org/10.24815/jpsi.v5i2.9810

Noma, L. D., Prayitno, B. A., \& Suwarno. (2016). PBL untuk meningkatkan kemampuan berpikir tingkat tinggi siswa kelas X SMA. Bioedukasi, 9(2), 62-66. doi: https://doi.org/10.1364/OL.36.003374

Pamungkas, M. S. H., Mulyani, S., \& Saputro, S. (2017). Penerapan model pembelajaran poe dengan metode praktikum untuk meningkatkan rasa ingin tahu dan prestasi belajar kimia siswa. Paedagogia, 20(1), 4660. doi: https://doi.org/10.20961/paedagogia.v20i1.16596

Riandari, F., Susanti, R., \& Suratmi. (2018). The influence of discovery learning model application to the higher order thinking skills student of Srijaya Negara Senior High School Palembang on the animal kingdom subject matter. Journal of Physics: Conference Series, 1022(1). doi: https://doi.org/10.1088/1742-6596/ 1022/1/012055

Rini, A. P., Suryani, N., \& Fadhilah, S. S. (2018). Development of the Predict Observe Explain (POE)-based Thematic Teaching Materials. International Journal of Educational Research Review, 4(1), 1-7. doi: https: //doi.org/10.24331/ijere.458067

Rochman, S., \& Hartoyo, Z. (2018). Analisis high order thinking skills (HOTS) taksonomi menganalisis permasalahan fisika. Science and Physics Education Journal (SPEJ), 1(2), 78-88. doi: https://doi.org/ 10.31539/spej.v1i2.268

Rosdianto, H., Murdani, E., \& Hendra. (2017). Implementasi model embelajaran POE (Predict Observe Explain) untuk meningkatkan pemahaman konsep siswa pada materi hukum newton. Jurnal Pendidikan Fisika, 6(1), 55-59. doi: https://doi.org/10.22611/jpf.v6i1.6899

Rubiyanto, B. A. J., Marjono, \& Prayitno, B. A. (2016). Penerapan model discovery learning pada materi ekosistem untuk meningkatkan kemampuan berpikir tingkat tinggi siswa kelas X SMA. Bio-Pedagogi, 5(1), 6-14. Retrieved from https://jurnal.uns.ac.id/pdg/article/view/5394/4792

Saleh, E. A. A. (2018). The effect of using the guided discovery method on enabling the students with intellectual disability to acquire some pre-academic mathematical concepts in the kingdom of saudi arabia. International Journal of English Linguistics, 8(3), 108. doi: https://doi.org/10.5539/ijel.v8n3p108

Setiadi, I., \& Irhasyuarna, Y. (2017). Improvement of model student learning through the content of solutions guided discovery buffer. IOSR Journal of Research \& Method in Education (IOSRJRME), 07(01), 01-09. doi: https://doi.org/10.9790/7388-0701050109

Sharma, K. (2013). Human development and South East Asian countries: Special emphasis on India. Journal 
of Education and Health Promotion, 2(1), 45. doi: https://doi.org/10.4103/2277-9531.117414

Sucipto, S. (2017). Pengembangan ketrampilan berpikir tingkat tinggi dengan menggunakan strategi metakognitif model pembelajaran problem based learning. Jurnal Pendidikan (Teori Dan Praktik), 2(1), 63-71. doi: https://doi.org/10.26740/jp.v2n1.p77-85

Sugiyono. (2014). Educational research methods quantitative, qualitative approach and R\&D. Retrieved from https://scholar.google.com/scholar?cluster=13608740209263721497\&hl=en\&oi=scholarr

Sulistyowati, N., Widodo, A. T., \& Sumarni, W. (2012). Efektivitas model pembelajaran guided discovery learning terhadap kemampuan pemecahan masalah kimia. Chemistry in Education, 1(2), 49-55. Retrieved from https://journal.unnes.ac.id/sju/index.php/chemined/article/view/980

Tan, E., \& So, H. J. (2019). Role of environmental interaction in interdisciplinary thinking: from knowledge resources perspectives. Journal of Environmental Education, 50(2), 113-130. doi: https://doi.org/10. 1080/00958964.2018.1531280

Wardani, S., Nurhayati, S., \& Safitri, A. (2016). The Effectiveness of the guided inquiry learning module towards students? Character and concept understanding. International Journal of Science and Research (IJSR), 5(6), 1589-1594. doi: https://doi.org/10.21275/v5i6.NOV164512

Wulan, D. A., Susanti, E., \& Aisyah, N. (2017). Meningkatkan kemampuan berpikir tingkat tinggi siswa SMA melalui teknik probing-promtng. JES-MAT, 3(2), 205-216. doi: https://doi.org/10.25134/jes-mat.v3i2.694

Wulandari, R. R. A., Yamtinah, S., \& Saputro, S. (2015). Instrumen two tier test aspek pengetahuan untuk mengukur Ketrampilan Proses Sains (KPS) pada pembelajaran kimia untuk siswa SMA/MA kelas XI. Pendidikan Kimia (JPK), 4(4), 147-155. Retrieved from https://jurnal.fkip.uns.ac.id/index.php/kimia/ article/view/6638/4529

Yulianti, S. H., Juanengsih, N., \& Mardiati, Y. (2018). POE learning model: The effect on student process on the coordination system concept. JPPS ( Jurnal Penelitian Pendidikan Sains ), 8(7), 1542-1546. Retrieved from https://journal.unesa.ac.id/index.php/jpps/article/view/3858/2188

Yurahly, D., Darmadi, I. W., \& Darsikin, D. (2014). Model pembelajaran guided discovery dan direct instruction berbasis keterampilan proses sains siswa SMA Negeri 4 Palu. Jurnal Pendidikan Fisika Tadulako Online (JPFT), 2(2), 43-47. doi: https://doi.org/10.22487/j25805924.2014.v2.i2.2856

Yuriza, P. E., Sigit, D. V., Biologi, M. P., Jakarta, U. N., Jakarta, U. N., Biologi, P., \& Jakarta, U. N. (2018). Hubungan antara kemampuan berpikir tingkat tinggi dan tingkat kecerdasan dengan kemampuan literasi sains pada siswa SMP. Biosperjpb, 11(1), 13-20. doi: https://doi.org/10.21009/biosferjpb.11-1.2 